\title{
Istorijos vaidmuo Lietuvos - Rusijos santykiuose
}

\begin{abstract}
Valstybiniu tarpusavio santykiu istorija yra elementari ju sambūvio dalis, ju kultūrinio gyvenimo apraiška. Tačiau jeigu istorijos vaidmuo santykiuose tarp valstybiu yra didelis, jeigu jis apima ne tik kultūros, bet ir politikos sferą, tai nèra geras ženklas. Paprastai jis liudija, kad tos valstybės dar neturi nusistovejjusios pilietinės identifikacijos, kad ju santykius dar veikia ivvairios ideologijos, mitai, versijos ar tiesiog spekuliacijos, kad pagaliau jos turi viena kitai įvairiu pretenziju, menamu ir teritoriniu, ir todèl praktiškai tos valstybès negali turèti normaliu partnerystės ir bendradarbiavimo santykių. Kita vertus, dèl tokios padèties kenčia ir istorija. Ji praktiškai verčiama ị ideologiją, nes besivaržančioms valstybẻms reikia ne objektyvios istorijos, bet ju poziciją pagrindžiančios ir priešininko poziciją paneigiančios versijos. Straipsnyje bus aptariama istoriniu interpretaciju i itampa, kuri šiandien yra tarp Lietuvos ir Rusijos, bei tos ittampos genezè, taip pat aptariamas tos įtampos neigiamas poveikis Lietuvos - Rusijos santykiams apskritai kaip santykiams tarp valstybiu, taip pat ieškant kelių tai įtampai mažinti.
\end{abstract}

\section{Ivadinès pastabos}

Lietuvos - Rusijos santykiuose istorijos vaidmuo nuo seno buvo didelis, gal net lėmè tuos santykius. Viduramžiais aktualiausias klausimas buvo toks: ar Lietuvos Didžioji Kunigaikštystė turi savarankišką savo legitimumą, ar ji tėra viena iš suirusios senosios Kijevo Rusios skeveldru, kurias buvo užsimojusi surinkti Maskvos Didžioji Kunigaikštystė? Nuo to, kaip bus atsakyta į tą klausimą, priklausè ir Lietuvos, ir Rusijos, ir, beje, net viso regiono tarp Baltijos ir Juodosios jūrų likimas. Istorijos tyrimai skleide kitokią LDK prigimtį nei rusiškos valstybės Kijeve ar Maskvoje, bet tie tyrimai negalëjo vienareikšmiškai atsakyti į iškeltą klausimą. Be to, objektyvi istorija buvo tiesiog nereikalinga, nes kiekviena pusė norëjo turèti tokią versiją, kokia jai buvo parankesnè. Pavyzdžiui, pagal LDK populiarią versiją, lietuviškos šaknys ejjusios iš Italijos ${ }^{1}$. Pagal Maskvos versiją, "ginčas tarp Gedimino ir Kalitos - tai šeimyninis ginčas, tai ginčas - kas valdys Rusiją “2

* Dr. Česlovas Laurinavičius - Lietuvos istorijos instituto vyresnysis mokslinis bendradarbis, XX amžiaus istorijos skyriaus vedèjas. Adresas: Kražių 5-215, Vilnius, tel. 2611787, el. paštas laurinav@yahoo.com.

${ }^{1}$ Vijūkas - Kojelavičius A., Lietuvos istorija. Kaunas, 1989, p. 44-46.

${ }^{2}$ Ustrialov N. Izsledovanije voprosa, kokoje mesto v Russkoj istorii dolžno zanimat Velikoje Kniažestvo Litovskoje? Sankt Peterburg, 1839, p. 36. 
Kadangi į ideologizuotus istorijos klausimus vieningo atsakymo nebuvo ir negalëjo būti, klausimas sprendèsi mūšių laukuose. Praktiškai tai reiškè nuolatinius karus tarp LDK ir Maskvos. Tuos karus skirdavo tik paliaubų laikotarpiai, nes tikros taikos negalëjo būti tarp subjektu, kurie vienas į kitą žiūrëjo kaip į intrigos pagimdytą antrininką, kaip į teritorijų arba identiteto vagị.

Tiesa, tas ginčas buvo aktualus tik diduomenei, nes plačiosios liaudies masės abiejose pusėse jam buvo abejingos. Mat tos masès buvo baudžiavos, beteisės, bemokslės ir rekrūtuojamos kautynèms kaip patrankų mėsa. Kadangi Rusijoje tos mėsos buvo daugiau, tokia padètis galu gale baigėsi LDK - nors ir sajungoje su Lenkija - žlugimu. Faktiškai nugalëjo rusiškoji istorinè versija, išreikšta carienės Jekaterinos II žodžiais: „ottorženych vozvratych“ (atplèštus sugrąžint). Dèl XVIII amžiaus pabaigos įvykių Lietuva atsidūrẻ didžiulèje Rusijos imperijoje, kurioje netgi Lietuvos vardas buvo paslèptas po rusišku gubernijų tinklu.

Naujaisiais laikais, arba vadinamojo modernizmo epochoje, pasikeite požiūris į valstybės pagrindą. Valdovo legitimumą pakeitè demokratinis tautos apsisprendimo principas. Ir 1918 metais Lietuvos valstybè vẻl atsikūrè, dabar jau, regis, visiškai skirtinga nuo Rusijos, nes moderniają Lietuvos valstybę formavo unikalią lietuviu kalbą turinti tauta. Deja, priešiškumas ir kova už savą autentišką identitetą tarp Lietuvos ir Rusijos nesumažejo.

İsisiautejusios moderniosios ideologijos iškraipe arba tiesiog pakeitè tautos sąvoką. Pagal išplitusią komunistinę ideologiją, vietoje tautos buvo gudriai pasiūlyta liaudies sąvoka: galima sakyti padarytas paprastas vertimas iš rusiško narod ir todèl vèl iškilo metafizinis klausimas, ar lietuvių tauta demokratiniu būdu apsisprendè gyventi nepriklausoma, ar, priešingai, buvo sutrukdyta liaudies sprendimui likti kartu su Rusijos liaudimi. Nors istorija aiškiai liudijo tautos apsisprendimo labui, vienareikšmiškai ji vèl negalëjo atsakyti į tą klausimą.

Ginantis nuo tautos sąvokos socialinio iškraipymo, bandyta tautą pernelyg sureikšminti, ieškota apsaugos net rasiniame tautos pakaitale. Dẻl to regione susidarẻ milžiniška įtampa, ir dèl šios priežasties laimëjo didesnę jègą turinti rusiškoji - liaudies bendrumo - versija. Lietuva vèl atsidūrẻ Rusijos imperijoje, tik dabar originaliai pavadintoje TSRS kaip didžiulès sovietinès liaudies lietuviškas etnografinis atspalvis. O vienas sovietų diplomatas (turimas galvoje Ivan Maiskij), aiškindamas apie tai, kas įvyko 1940 metais, pasiūlè netgi tokią alegoriją: kartą valstietis Ivanas (suprask, svarbiausiasis liaudies atstovas) per išgertuves buvo per daug apsvaigęs, ir vagys pavogè iš jo padargus, bet kai Ivanas išsiblaive, jis susigrąžino tai, kas iš jo buvo atimta. Beje, tenka pastebėti, toks paaiškinimas daug ką tiek Rytuose, tiek ir Vakaruose tenkino.

XX amžiaus pabaigoje individo laisvės idëja suskaldè moderniają komunizmo ideologiją, ir Lietuvos valstybè vèl atsikūrè - dabar jau ne tiek tautinè ir juo labiau ne liaudies, bet demokratinè. Susikūrè ir Rusijos Federacija, pavadinusi save demokratine. Tačiau greitai ėmė aiškèti, kad ta Rusijos Federacija negali būti demokratinè, nes pirmiausia neaišku, kokiu pagrindu egzistuoja ta jos federacija, ir kad demokratijos sąlygomis toji federacija paprasčiausiai gali toliau irti iki begalybės. Tokia perspektyva išgąsdino rusus, ir jie ėmė nusisukti nuo demokratijos, ėmè mintimis grižti i praeitį, svajoti ir save identifikuoti su 
buvusia Rusijos imperija. Tuo tarpu Lietuvoje demokratija tvirtinosi sẻkmingiau nei Rusijoje, tačiau taip pat ne be problemu, ir tas problemas lietuviai ėmé sieti su Rusijos neigiama įtaka. Todèl šiandien tarp Lietuvos ir Rusijos vèl formuojasi konfliktų ir vis labiau įtempta situacija.

Ir vèl abi pusės savo poziciją bando pagristi istorija. Klausimas dabar keliamas taip: ar 1940 metais buvo okupacija iš Rusijos (TSRS) pusės Lietuvos atžvilgiu, ar nebuvo? Šis klausimas abiems šalims yra labai aktualus ir labai reikšmingas, kadangi nuo atsakymo i ji priklausys tolesnè Lietuvos ir Rusijos tiek materialinè, tiek ir identifikacinė raida. Jeigu okupacija buvo, tai tada Rusija atsakinga už agresiją - už visais atžvilgiais neteisètą akciją prieš suverenią Lietuvos valstybę. Tai galètų reikšti, kad Rusija, kaip tiesioginè TSRS paveldètoja, už tą istorinį ir teisinį nusikaltimą turètų atsiprašyti Lietuvos ir sumokèti jai milijardinę kompensaciją. O kas bus po to su pačia Rusija, kai iš jos pagal lietuvišką precedentą atitinkamu kompensacijų tikriausiai pareikalaus ir visos dabartinès Rusijos kaimynės ir net visos būsimos - ar ji apskritai išsilaikys kaip valstybė. Tai, Lietuvos požiūriu, tik pačios Rusijos reikalas... Bet pačiai Rusijai tokia perspektyva, suprantama, visai nepriimtina.

Tačiau jeigu okupacijos nebuvo, tai tuomet buvo - tegul ir šiek tiek paspaustas ar pagąsdintas, bet vis viena autentiškas - Lietuvos apsisprendimas įsijungti į Rusijos (TSRS) valstybès sudèti, tiksliau, apsisprendimas grįžti į istoriškai determinuotą ir ta prasme natūralų bendrą būvị su Rusija. O jeigu taip, tai tuomet Lietuvai tektų visai kitaip skaičiuoti ir, kas kam skolingas. Bet svarbiausia, tokios versijos atveju kiltu pagrịstas įtarimas, kad gal ir paskutinysis Lietuvos atsiskyrimas nuo Rusijos - tik laikinas reiškinys, tik vertybiu perkainojimo rezultatas. Tiesa, dabartiniu laiku bendro gyvenimo pagrindu nebetinka nei dinastijos legitimumas, nei komunistinè ideologija. Bet galima ieškoti ir surasti naują susijungimo pagrindą, jeigu, suprantama, tai natūralus imanentinis ne tik Rusijos, bet ir Lietuvos interesas. O iki tol, kol tas pagrindas bus surastas, Lietuva gali egzistuoti ir kaip nepriklausoma nuo Rusijos ir gali net įsijungti i įvairias sajungas - esmės tai nekeis... Suprantama, kad net jeigu tas naujas „,susijungimo su Rusija pagrindas“ ir neatsiras, pati tokia versija yra visiškai nepriimtina Lietuvai pirmiausia jos identiteto požiūriu.

Taigi Lietuva ir Rusija nori pagristi savo pozicijas ir atsakymo desperatiškai ieško istorijoje. Bet vèlgi ar gali istorija vienareikšmiškai ir be apeliaciju atsakyti į keliamą klausimą ir išspręsti dilemą? Žinoma, kad teoriniu požiūriu istorija negali griežtai atsakyti ị klausimą - kaip buvo. Tokio atsakymo viso labo galima tikètis tik iš ideologijos pusės. Bet istorija gali nemažai pasakyti apie tai, kas ir kaip buvo. O toks pasakymas gal galètų sudaryti esmę atsisakyti ideologizuotos istorijos ir jungti kitas sritis, pavyzdžiui, politiką, diplomatiją, pagaliau etiką ir moralę, kurios gal geriau padètų spręstu ginčą.

Taigi pasižiūrèkime, ką gali pasakyti istorija pastarojo Lietuvos ir Rusijos ginčo atžvilgiu, konkrečiai vienos ar kitos versijos labui. 


\section{Pirmasis liudijimas: kodèl galima teigti, kad okupacija buvo?}

Pagrindas teigti, kad Lietuvos okupacija iš TSRS pusės buvo, yra TSRS ir Vokietijos slapti protokolai, pasirašyti 1939-1941 metais (turimi omenyje Molotovo ir Ribbentropo pasirašyti slapti protokolai 1939 metu rugpjūčio 23 d., 1939 metu rugsëjo 28 d., taip pat slaptas priedas prie 1941 metų sausio $10 \mathrm{~d}$. sutarties). Tiems, kurie susigaudo didžiosios politikos srityje, tos sutartys negali kelti abejoniu, kad pagal jas Vokietija sudarè sąlygas Sovietų Sajungai sunaikinti Lietuvos valstybę. Tą TSRS ir padare 1940 metų vasarą. Kadangi XX amžiuje ìsigalinčiu teisès, politikos bei moralès principu požiūriu vadinamasis sferu pasidalijimas tarp didžiujų valstybių ir tuo pasidalijimo pagrindu atliktas mažos valstybės sunaikinimas jau buvo nepriimtinas, TSRS dèjo visas pastangas nuslèpti bei neigti slaptu protokolu su Vokietija egzistavimo faktą. TSRS galèjo taip elgtis dèl joje egzistavusio totalitarinio režimo, ir tokia padètis tęsèsi net 50 metu.

Michailo Gorbačiovo dèka Sovietų Sajungoje prasidejjus viešumo bei demokratizacijos kampanijai toliau neigti slaptu protokolų egzistavimo tapo nebeįmanoma. Todèl 1989 metu gruodžio 24 d. vadinamasis Liaudies Deputatu Suvažiavimas priemė rezoliuciją (1432 balsais - už, 252 - prieš, 264 - susilaikè), pagal kurią Molotovo ir Ribbentropo slaptieji protokolai buvo kvalifikuoti kaip niekiniai ir „,negaliojantys nuo ju pasirašymo momento“ , kadangi „dèl jų buvo pažeistas trečiujų valstybių suverenumas bei nepriklausomybe $\dot{e}^{/ 3}$.

Tačiau toks pripažinimas iškèlè Lietuvos (taip pat 1940 metų sunaikintu Latvijos bei Estijos) priklausymo TSRS teisètumo klausimą, SSSR propagandistai ėmèsi ieškoti priemonių, kaip išsaugoti TSRS faktinį teritorinį vientisumą. Tokiam tikslui buvo panaudoti du argumentai.

Pagal vieną iš argumentų Vokietijos - TSRS slaptieji susitarimai esą neturëję ryšio su 1940 metais Baltijos valstybėse vykusiais procesais, kitaip tariant, tie susitarimai nelèmę Baltijos valstybių teisinès bei politinès padèties ir Baltijos valstybių egzistavimas nutrūkęs dèl kažkokių paprastai neįvardijamų „kitu aplinkybių ${ }^{4}$.

Kitas argumentas: nesvarbu net tai, kad 1939-1941 metų slaptieji Vokietijos bei TSRS susitarimai buvę niekiniai, ju galiojimas nutrūkęs 1941 metų birželio 22 d., kai Vokietija pradèjo karą prieš TSRS. mat, pradėdama kara, Vokietija drauge sulaužè „nepuolimo“ bei „draugystės ir sienu“" sutartis su TSRS. Be to, nutrūkęs ir slaptuju protokolų egzistavimas. Todèl tie slaptieji dokumentai nebeturëję poveikio tolesniam Lietuvos (taip pat Latvijos bei Estijos) likimui ${ }^{5}$.

\footnotetext{
${ }^{3}$ Soobščenije komissiji po političeskoi i pravovoi ocenkie sovietsko-germanskogo dogovora o nienapadenii ot 1939 goda, Pravda, 19891224.

${ }^{4} 1939$ metu ịvykiai - žvilgsnis iš pusės amžiaus distancijos. A. Jakovlevas atsako į "Pravdos" klausimus, Tiesa, 1989 m. rugpjūčio 19 d., nr. 191.

${ }^{5}$ Ten pat.
} 
Abu tie argumentai susiję vienas su kitu. Jie nesunkiai paneigiami ir kelti buvo, regis, tik dedant viltis ị tai, kad daugeliui žmonių bus sunku susigaudyti su tokios srities vingrybemis.

Iš tikrujų slaptuosiuose protokoluose nėra tiesmukiškai konstatuota, kad Vokietijai bei TSRS susitarus "TSRS okupuos ir aneksuos Lietuvos valstybę“. Ten tik pasakyta, kad „Lietuva pereina ị TSRS įtakos sferą“ ir kad TSRS „dèl savo interesu“" galės atlikti Lietuvos atžvilgiu „,specialius teritorinius bei politinius pertvarkymus " ${ }^{\prime \prime}$. Tačiau tik neturinčiam visiško supratimo apie politiką arba neturinčiam paprasčiausios sąžinės gali kilti abejoniu, ką tokie pasakymai konkrečioje situacijoje galëjo reikšti ir ką jie reiškè.

Netiesioginiu būdu (arba vadinamuoju konkliudentiniu metodu) visiškai nesunku įrodyti, kad minètos frazės reiškè susitarimą sunaikinti valstybę. Pirma, teiginys „pereina ị TSRS įtakos sferą" praktiškai reiškè, kad maža valstybè Lietuva tampa visiškai priklausoma nuo didelès valstybès - TSRS - valios, o kita didelè valstybè - Vokietija konkrečioje situacijoje vienintelè, galinti neleisti TSRS veikti Lietuvos atžvilgiu, kaip ji tik sugalvoja, būtent sutinka su tuo, kad Lietuvos atžvilgiu TSRS veiktu, kaip tik pageidauja. Be to, išlikę sovietu - naciu slaptų derybu protokolai bei susirašinejjimo dokumentai nepalieka abejonių, kad slaptieji susitarimai atvėrè kelią Sovietų Sajungai sunaikinti Baltijos valstybes, kartu ir Lietuvą ${ }^{7}$. Ypač reikšmingas ženklas, liudijęs apie ruošiamą Lietuvos valstybès sunaikinimą, buvo Lietuvos teritorijos skaldymas: pagal slaptą 1939 metų rugsëjo 28 d. protokolą, Lietuvos dalis Suvalkijoje turëjo būti atplèšta nuo sovietams pereinančios didžiosios Lietuvos dalies ir palikta Vokietijai. Pagaliau po slaptujų TSRS - Vokietijos susitarimų įvykusių TSRS - Lietuvos derybų dokumentai liudija, kad Stalinas pats asmeniškai pasakẻ Lietuvos užsienio reikalų ministrui Juozui Urbšiui apie susitarimą su Vokietija dẻl įtakos sferu pasidalijimo. Taigi pats Stalinas pripažino, kad Lietuva yra perleista į TSRS ittakos sfera, ir dèl šios priežasties TSRS gali pasielgti su Lietuva, kaip nori ${ }^{8}$. O toji aplinkybė, kad TSRS tuojau pat nesunaikino Lietuvos, nekeičia esmės. Akivaizdu, kad dèl slaptujų susitarimų su Vokietija TSRS panaikino tiek objektyvias, tiek ir subjektyvias kliūtis tam sunaikinimui.

Taigi nebebuvo jègos, kuri būtu galejusi sutrukdyti TSRS ,kaip pagrindinės valdžios, veiksmams. Be to, Lietuva, sužinojusi apie savo tikrą padèti, (panašiai kaip Latvija bei Estija supratusios apie savo tikrą padètį), buvo moraliai palaužta prieš TSRS veiksmus. Todèl TSRS galejo šantažu primesti Lietuvai sutarti, pagal kurią į Lietuvą buvo įvestas Raudonosios armijos kontingentas ${ }^{9}$.

\footnotetext{
${ }^{6}$ TSRS - Vokietija 1939. TSRS ir Vokietijos santykių dokumentinè medžiaga 1939 metu balandžio - spalio mèn., t. 1, Vilnius, Mokslas, 1989, p. 62, 109-110.

${ }^{7}$ Lietuvos žlugimo preliudas. 1939 metu rugsejjo 27-29d. Vokietijos - TSRS derybų Maskvoje dokumentai. Paruošè Nerijus Šepetys. Naujasis židinys - Aidai, 2002 metų rugséjis - spalis, nr. 9-10, p. 457.

${ }^{8}$ Lietuvos okupacija ir aneksija 1939-1940. Dokumentu rinkinys, Vilnius, Mokslas, 1993, p. 71.

${ }^{9}$ Ten pat, p. 95-98, 101-104, 125-147.
} 
Po to TSRS galëjo netrukdoma kurị laiką žaisti su Lietuva kaip katẻ su pele, kol galiausiai apsisprendusi TSRS galëjo primesti Lietuvai išgalvotus kaltinimus (apie sovietiniu kariu grobimą ar karinės sutarties su Latvija bei Estija prieš TSRS sudarymą) ir ultimatumo keliu reikalauti iš Lietuvos įsileisti i savo teritoriją Raudonają armiją ${ }^{10}$. Galiausiai galëjo lemti reikiamų asmenų išrinkimą i vadinamajį Liaudies Seimą ir spaudimu priversti tą Seimą pareikšti apie norą prisijungti prie TSRS $^{11}$.

Kita vertus, ne visai pagrịstas ir teiginys, kad 1941 metų birželio $22 \mathrm{~d}$. nutrūko visi TSRS - Vokietijos susitarimai. Tiesa, kad nutrūko viešos sutartys („,nepuolimo“" ,draugystès ir sienu““ bei kitos), tačiau vargu ar nutrūko slapti susitarimai iš principo dèl Baltijos valstybiu sunaikinimo. Juk tas faktas, kad Hitleris, okupavęs Pabaltiji, neleido atkurti Baltijos valstybiu, argi nebuvo signalas Stalinui, kad nesvarbu, kaip baigtųsi jųdviejų tarpusavio karas, jųdvieju slaptas susitarimas dèl Baltijos valstybiu sunaikinimo tebeveikia.

Pagaliau net jeigu sutiktume su teiginiu, kad 1941 metu birželio $22 \mathrm{~d}$. nutrūko visi vieši ir slapti TSRS ir Vokietijos susitarimai, tai nekeitė TSRS požiūrio ị Baltijos valstybiu padètị, nes dèl tų slaptų susitarimų buvo padaryti vieši oficialūs Baltijos valstybių ijungimo į TSRS aktai, kurie tebeveikè ${ }^{12}$.

Tik su Lenkijos emigrantine vyriausybe 1941 metų liepos $30 \mathrm{~d}$. TSRS pasirašè deklaraciją, pagal kurią pripažino, kad „visi TSRS - Vokietijos 1939 metais padaryti susitarimai Lenkijos teritorijoje negalioja ${ }^{\prime 13}$. Tiesa, ta deklaracija buvo anuliuoti ne slapti protokolai, o vieša 1939 metu rugsejjo $28 \mathrm{~d}$. TSRS Vokietijos sutartis dèl sienu, kuri jau ir taip nebegaliojo Vokietijai pradejjus karą prieš TSRS ${ }^{14}$. Bet praktiškai toji deklaracija turejo reikšti, kad juridiškai nebeveikè TSRS vidine teisé tose Lenkijos teritorijose, kurias TSRS 1939 metu pabaigoje buvo oficialiai pavadinusi kaip savo. Todẻl iš principo ị lenkiškają jurisdikciją galèjo grižti jos buvę piliečiai, prieš tai jau buvę kaip TSRS piliečiai ${ }^{15}$. (Beje, tam tikru požiūriu ta TSRS - Lenkijos deklaracija buvo aktuali ir Lietuvai, nes ji lietė Vilniaus kraštą. Vilniaus priklausomybės klausimą lėmè tik 1943 metais Teherano konferencijoje priimtas sprendimas iš principo dèl Lenkijos rytinės sienos nustatymo pagal vadinamają Curzono liniją $\left.{ }^{16}\right)$.

Bet TSRS - Vokietijos susitarimas dèl Baltijos valstybiu prijungimo prie TSRS nebuvo atšauktas. Todèl TSRS požiūriu, jos vidinè teisẻ Pabaltijo tautų atžvilgiu tebeveikè, ir būtent remdamiesi ta teise - tai yra savanorišku Pabaltijo tautu apsisprendimu įstoti į TSRS ir dèl šio tariamo pritarimo dèl apsisprendimo - sovietiniai diplomatai galëjo vertinti Pabaltijji, kaip teisėtą TSRS dalị. O

${ }^{10}$ Ten pat, p. 180-265.

${ }^{11}$ Baltijos valstybiu užgrobimo byla. JAV Kongreso Ch. J. Kersteno komiteto dokumentai 1953-1954 metai.Vilnius, DUKA, 1997, p. 323-353.

${ }^{12}$ Ten pat, p. 265-271, 293, 352-356.

${ }^{13}$ Dokumenty i materialy po istorii sovietsko - polskich otnošenij, t. VII. Maskva, Nauka, 1973, p. 208.

${ }^{14}$ TSRS - Vokietija 1939, (6 išnaša) p. 107-108.

${ }^{15}$ Historia dyplomacji Polskiej, t.V, 1939-1945, Warszawa, 1999, p. 211- 228.

${ }^{16}$ Sovietskij Sojuz na mieždunarodnych konferencijach perioda Belikoj otečestvennoj boiny, 1941-1945gg: Sbornik dokumentov, t. 2, Tegeranskaja konferencija, Moskva, 1984; 
kadangi toji TSRS vidaus teisė faktiškai buvo realizuota TSRS - Vokietijos slaptų susitarimų dèl įtakos sferų pasidalinimo dẻka, Sovietų Sajunga kiek įmanydama ir kaip galedama neige tų slaptu protokolų egzistavimą. Nes buvo akivaizdu, kad, pripažinus neteisètų protokolų egzistavimą ir juos anuliavus, iškart bus nuplautas teisètumas ir viešosios TSRS teisès, pagal kurią Sovietų Sajunga laikè valdanti Pabaltiji teisètai.

Tuo metu, kai 1989 metais gruodžio 24 d. Liaudies deputatų suvažiavime paskelbė 1939-1941 m. slaptus susitarimus su Vokietija niekiniais, Baltijos tautos jau buvo išreiškusios reikalavimą atstatyti jų nepriklausomybę. Todèl TSRS toliau galëjo pretenduoti į Pabaltijo tautu valdymą tik remdamasi jèga. TSRS juridiškai atsisakè teisių į Pabaltiji tik 1991 metų rugsëjo 6 d., kada TSRS prezidentas Gorbačiovas pripažino Baltijos valstybių nepriklausomybę.

Taigi turint galvoje vien tas išvardytas aplinkybes, vargu ar gali moralus bei tam tikrą supratimą apie santykius tarp valstybių turintis asmuo abejoti, kad 1940 metais iqvykiai Lietuvoje, kaip ir Latvijoje bei Estijoje, buvo TSRS slaptu susitarimų su Vokietija tiesioginè ir nulemtoji pasekmè, kad dèl šių susitarimu TSRS atliko prievartini agresijos veiksmą prieš Baltijos valstybes, ir bet kokios „kitos aplinkybės“ negalëjo pakeisti tų agresyvių veiksmų esmès.

Kaip jau minèta, TSRS Liaudies deputatu suvažiavimas po ilgų dvejoniu bei blaškymųsi praktiškai prie tokios išvados buvo priejęs ir 1989 metų gruodžio 24 d., kai paskelbè nutarimą dèl TSRS ir Vokietijos 1939 metų nepuolimo sutarties politinị bei teisinị įvertinimą. Tame nutarime, be kita ko, buvo taip pasakyta: „Suvažiavimas konstatuoja, kad 1939 metų rugpjūčio 23 d. protokolu ir kitais slaptaisiais protokolais, kurie buvo pasirašyti su Vokietija 1939-1941 metais, nustatytos TSRS ir Vokietijos „interesų sferu“ " ribos ir kiti veiksmai teisés požiūriu prieštaravo kai kurių trečiuju šalių suverenumui ir nepriklausomybei... Stalinas ir jo pakalikai protokolus panaudojo ultimatumams kelti ir jègai spausti kitas valstybes, pažeidžiant teisinius joms prisiimtus įsipareigojimus “"17.

Atkreiptinas dėmesys į nutarimo frazę „teisės požiūriu“. Ji, regis, atsirado kaip tam tikras kompromisas, nes demokratiškai nusiteikę deputatai reikalavo sąvokos "tarptautinès teisès požiūriu“, bet valdžios atstovai (pavyzdžiui, Valentinas Falinas) teigè, kad tuo metu, tai yra, 1939-1945 metais, tarptautinè teisè dar neegzistavusi, o veikusios vien paskiros sutartys ${ }^{18}$. Matyt, dèl tos priežasties nutarime atsirado ir tokia pastraipa:

„Suvažiavimas pažymi, kad tuo laikotarpiu TSRS santykiai su Latvija, Lietuva, Estija buvo reguliuojami sutarčių sistema. Pagal 1920 metų taikos ir nepuolimo sutartis, sudarytas 1926-1933 metais, jų dalyviai ịsipareigojo bet kokiomis aplinkybėmis gerbti vienas kito suverenumą, teritorijos vientisumą ir neliečiamybę. Panašių įsipareigojimų Sovietų Sajunga turëjo Lenkijai ir Suomijai“ ${ }^{\prime 19}$.

\footnotetext{
${ }^{17}$ Soobščenije komissiji po političeskoi i pravovoi ocenkie sovietsko-germanskogo dogovora o nienapadenii ot 1939 goda, (3 išnaša).

${ }^{18}$ Landsbergis V., Lüžis prie Baltijos, Vilnius, 1997, p. 143.

${ }^{19}$ Soobščenije komissiji po političeskoi i pravovoi ocenkie sovietsko-germanskogo dogovora o nienapadenii ot 1939 goda, Pravda, (3 išnaša).
} 
Kaip besvarstytumète, 1989 metu gruodžio 24 d. LD suvažiavimo nutarimas atrodo pakankamai artimas išvadoms, kurias galima daryti, kai vertintumète 1939-1940 metų įvykius pagal sąžinę bei objektyvumą. Tačiau vèliau Maskvos politika ima tolti nuo tokios pozicijos ir įvairiais sofizmais išsisukinëja nuo politinės atsakomybės už atliktą prievartą Baltijos valstybiu atžvilgiu.

Pagrindinè tokia apraiška - tai bandymas atskirti 1940 metų TSRS veiksmus prieš Baltijos valstybes, $t$. y. atskirti aneksiją nuo okupacijos, ir, viena vertus, pripažistant aneksiją, atliktą netgi naudojant grasinimą jẻga, drauge neigti buvusios okupacijos faktą.

Okupacija neigiama remiantis tuo argumentu, kad TSRS 1940 metų birželio viduryje įvedè į Baltijos valstybes didžiulę savo kariuomenę ne dèl karo paskelbimo ir netgi ne dẻl karo veiksmų nepaskelbus karo, bet dẻl sutarimų su Baltijos valstybemis ${ }^{20}$. Tiesa, pripažįstama, kad tos sutartys buvo ultimatyviu reikalavimu iš TSRS pusès rezultatas, tačiau esą tuometinè teisè nedraudusi grasinti jëga ${ }^{21}$. Be to, ultimatumu nebuvo reikalaujama, kad valstybè kapituliuotų kaip, pavyzdžiui, Vokietija reikalavo iš Austrijos 1938 metu pavasarį tiesiog prisijungti prie Reicho ar iš Čekoslovakijos 1939 metu pavasarị - pasiduoti Reicho protektoratui. TSRS reikalavo tik garantiju, kad 1939 metu tarpusavio pagalbos sutartys tarp TSRS ir Baltijos valstybių būtų vykdomos "garbingai ir sąžiningai". Vadinasi, ne tik rusų teisininkai bei propagandistai, bet ir oficialūs Rusijos vyriausybès atstovaiprieina prie išvados, kad Baltijos valstybių okupacijos nebuvo ${ }^{22}$. O véliau iqvykusi aneksija, nors ir atlikta darant kai kuriuos teisinius pažeidimus, buvę ne vienašališki TSRS veiksmai, bet jie įvykę dèl pačiu Baltijos tautų apsisprendimo. Taip, beje, išaiškèjo, kas buvo tos „,kitos aplinkybès", kurių savo laiku Aleksandras Jakovlevas nesiryžo įvardyti.

Žinoma, tokia Rusijos pozicija - tai tik desperatiškas išsisukinëjimas. Ją nesunkiai galima sukritikuoti. Nes neteisinga tos pozicijos pagrindinè tezè, kad tarptautinè teisè neva nedraudusi grasinti jega. Kad toks draudimas buvo, liudija kad ir JAV valstybės departamento pareiškimas 1940 metu liepos 23 d., kai jau sovietu tikslai sunaikinti Baltijos valstybes tapo akivaizdūs. Ten, be kita ko, buvo pasakyta:

„Per kelias pastarąsias dienas gėdingi procesai, kurių metu trijų nedidelių Baltijos respubliku - Estijos, Latvijos, Lietuvos - politinè nepriklausomybė bei teritorinis vientisumas buvo sąmoningai sunaikinti vieno iš didžiuju galingujų kaimynu, sparčiai artèja prie atomazgos..."

Mūsų Vyriausybẻs politika visiems žinoma. Jungtinių Valstijų žmonės priešiškai nusiteikę prieš bet kokius grobuoniškus veiksmus, nepriklausomai nuo to, ar jie įvykdomi tiesiogiai panaudojant jègą, ar tiktai grasinant ją panaudoti. Šios šalies žmonès vienodai priešingi bet kokios formos intervencijai, kokia valstybė ją vykdytu, tegul ir labai galinga, nesvarbu, į kokius kitos suverenios valstybès reikalus kištųi, tegul net ir visai silpnos.

${ }^{20}$ Lietuvos okupacija ir aneksija 1939-1940. Dokumentu rinkinys, p. 265-268.

${ }^{21}$ S. Černičenko. Ob „okkupacii Pribaltiki i narušenii prav russkojazyčnogo naselenija. Meždunarodnaja žizn. 2004/4; S. Cernišenko. Okkypacii ne bylo, Moskovskij komsomolec v Latvii, 2004 08 24;

${ }^{22}$ RF užsienio reikalų ministro Vladimiro Čižovo 2005 metų liepos 18 d. pareiškimas // www.regnum.ru. 
Šie principai kaip tik ir sudaro tą pagrindą, kuriuo remiasi 21 suverenios respublikos, sudarančios Naujajį Pasauli, santykiai.

Jungtinės Valstijos ir toliau laikysis šių principu, kadangi Amerikos žmonès yra įsitikinę, kad jeigu doktrina, įūnijanti šiuos principus, vèl neįsivyraus tautu tarpusavio santykiuose, tai proto, teisingumo, taip pat įstatymų normos kitaip tariant, pačios moderniausios civilizacijos pagrindas - negalès būti išsaugotos ${ }^{23}$.

TSRS veiksmus 1940 metų Baltijos valstybių atžvilgiu visiškai pagrįstai galima pavadinti kaip netiesioginę agresiją. Ir nerimta bandyti ịrodinèti, kad jeigu tarptautinè teisè draudè agresiją kaip tokią, tai ji neva nedraudè netiesioginès agresijos. Pačių sovietų veikèjų oficialūs pareiškimai liudijo, kad ir TSRS netiesioginę agresiją laikė nepriimtina. Pavyzdžiui, TSRS Užsienio reikalų liaudies komisaras Maksimas Litvinovas 1938 metų kovo mėnesį taip kalbëjo Tautu Sajungos Asamblëjoje:

„Tautų Sajunga neturètų keisti savo požiūrio ị tiesioginị kitų tautų teritorijų užgrobimą ar aneksiją, taip pat „tuos atvejus, kai tokios aneksijos maskuojamos kuriant marionetines „liaudies“ vyriausybes, kurios yra tariamai nepriklausomos, tačiau iš tikruju yra tiktai kaip užsienio agresoriaus priedanga ir priemonè $\dot{e}^{\prime 24}$.

Kitas TSRS Užsienio reikalų liaudies komisaras Viačeslavas Molotovas 1939 metų vasaros derybose su Didžiosios Britanijos ir Prancūzijos atstovais, sprendžiant garantijų Baltijos valstybėms klausimą, ypač energingai reikalavo garantijų toms valstybėms netiesioginés agresijos atveju ${ }^{25}$. Molotovas apeliavo ị tokios agresijos galimumą iš Vokietijos pusės, nors Vakarų sajungininkėms neliko abejoniu, kad tokiu reikalavimu sovietai siekia pridengti savo planuojamą netiesioginę agresiją prieš Baltijos valstybes. Dèl sutarties su Vakarų valstybèmis Sovietų Sajungai tuomet pasiekti nepavyko.

Svarbu pažymėti, kad Rusijos nuostata neigti okupacijos faktą ypač išryškëjo 2005 metų pavasarị, kuomet Rusija minëjo pergalès prieš hitlerinę Vokietiją 60-metį. Neabejotina, kad nacizmo sutriuškinimas turëjo milžinišką reikšmę Europai bei visam pasauliui. Taip pat negalima nuneigti, kad tame nacizmo triuškinime svarbiausią vaidmenį suvaidino Sovietų Sajunga ir visų pirmiausia rusų tauta. Taigi pelnytas Rusijos pasididžiavimas tuo savo vaidmeniu ir amžina atmintis žuvusiems toje kovoje.

Tačiau negalëjo nekristi į akis ta aplinkybė, kad pergalès prieš nacizmą minëjimu Rusijos valdžia akivaizdžiai siekẻ akcentuoti TSRS, kaip išvaduotojos, vaidmenį ir drauge pridengti, nutylèti arba tiesiog iškreipti tikrovę apie sovietinio režimo nusikaltimus prieš kitas suverenias tautas. Toji aplinkybė ypač skaudžiai palietė Baltijos valstybes, nes pagal Rusijos versiją jos pačios atsisa-

\footnotetext{
${ }^{23}$ Baltijos valstybių užgrobimo byla, (11 išnaša) p. 292.

${ }^{24}$ Hough W. J. H., The Annexation of the Baltic States and Its Effect on the Development of Law Prohibiting Forcible Seizure of Territory. New York Law School Journal of International and Comparative Law, 1985, Vol. 6, No. 2, p. 390.

${ }^{25}$ Baltijos valstybiu užgrobimo byla, (11 išnaša) p. 189; God krizisa 1938-1939, t. II, Maskva, 1990, p. 90.
} 
kiusios nepriklausomybės, o iš TSRS pusės jeigu ir būta neteisètų veikimo epizo$\mathrm{du}$, tai tie epizodai jokiu būdu negali menkinti TSRS, kaip išvaduotojos, misijos ir negali paneigti Baltijos valstybiu prijungimo prie TSRS teisètumo ${ }^{26}$.

Nenuostabu, kad Baltijos valstybės griebėsi kontrakcijų prieš tokią Rusijos propaganda, ir drąsiai galima teigti, kad ju pozicija pasaulio bendruomenëje sulaukè pakankamai didelio supratimo bei pritarimo, nors drauge ta pasaulio bendruomené pasistengè parodyti pagarbą ir Rusijai už jos istorinius nuopelnus, triuškinant nacizmą ${ }^{27}$.

\section{Antras liudijimas - kodèl galima abejoti, kad buvo klasikinè okupacija?}

Sovietinė armija 1940 metais iš tikrujų buvo ịsileista pagal sutartị - nei ginklu nesipriešino, nei Lietuvos Vyriausybẻ pareiškẻ oficialų protestą. Todẻl, kad didelè dalis iki tol opozicijoje buvusios inteligentijos suskubo paremtijau faktiškai okupantų valia sudaromą naująją vyriausybę ir be protestų dalyvauti tų pačiu faktinių okupantų organizuotuose rinkimuoseį Seimą. O tameSeime „prastūmus“ rezoliuciją dèl stojimo į TSRS nẻ vienas iš deputatų nebalsavo prieš. Aišku, galima sakyti, veikẻ baimè, kad su tavimi bus fiziškai susidorota. Tačiau taip pat galima sakyti, kad žymesnei daliai tautinès inteligentijos savas kailis buvo svarbiau už savos valstybès likimą. Be to, galima įtarti, kad protestų nebuvo ne tik dèl baimès, bet ir dèl akivaizdaus dalies bendru piliečių pritarimo socialistinių reformų perspektyvai.

Žinoma, galima apeliuoti ir į tai, kad 1940 metu vasarą buvo ypatinga padètis visoje Europoje. Viena po kitos nyko arba jau buvo išnykusios iš politinès arenos kur kas didesnès bei senesnės valstybės. Bet tuomet žvilgsnis neišvengiamai kryps į ankstesnius laikus ir kils klausimas, o kokią valstybės savimonę bei efektyvumą demonstravo, pavyzdžiui, Lietuva apskritai per visą nepriklausomybės laikotarpi.

Be abejo, visiems žinoma, kad praktiškai nuo nepriklausomos valstybės gyvavimo pradžios Lietuva kariavo su Lenkija, nes pastaroji buvo užèmusi istorinę Lietuvos sostinę - Vilnių. Toji aplinkybè, be abejo, buvo Lietuvos nelaimé, dèl kurios smarkiai išgyveno visi lietuviai. Bet kur kas mažiau žinoma tos nelaimés esmè. O tai ne tik kad Lenkija užgrobė Vilnių, kiek tai, kad patys lietuviai vieni negalëjo nelietuviško Vilniaus išlaikyti. Dar mažiau Lietuvoje žinoma (arba tiksliau - norima žinoti), kaip elgèsi Lietuva tai nelaimei ištikus. Deja, tenka

\footnotetext{
${ }^{26}$ Žymus RF politologas Sergejus Karaganovas viename savo straipsniu („,Rosijskaja gazeta“ 200509 23) taip apibūdino Rusijos propagandos karą su Baltijos valstybėmis: „Mes dèl vidinio silpnumo dažnai reaguojame neadekvačiai. Pavyzdžiui, ko buvo verta reakcija vien i reikalavimą pripažinti TSRS kaltę už Molotovo - Ribbentropo pakto pasirašymą! Su savo nežabota reakcija mes vos neužtemdème sėkmingai praejusios ir sutvirtinusios šalies prestižą Pergalès dienos šventès".

${ }^{27}$ Kaip pripažizstama ir Rusijoje, bandymai izoliuoti Baltijos valstybes per Pergalès dienos minejjimą nepavyko

(Kondrašov D., Front protiv Rossiji: napravlenije agressiji 20050328 // www.regnum.ru).
} 
konstatuoti, kad Lietuva savo elgesiu apskritai nepagelbẻjo nei savo įvaizdžiui, nei stiprino savo pozicijas tarptautinëje arenoje. Priešingai, ji savo elgesiu dažnai netgi kèlè grèsmę - ne tik sau, bet ir aplinkiniams.

Nieko nestebina, kad, jausdama grèsmę iš Lenkijos, Lietuva ieškojo didžiujų valstybių paramos. Tačiau - ne demokratinėse, nes jų teikiamos pagalbos Lietuva nesuprato arba nevertino, o Vokietijoje ir ypač Sovietų Rusijoje, be to, kad tos dvi didelés valstybés buvo nepatenkintos padètimi po I-ojo pasaulinio karo ir sieké naujo karo.

Štai keletas ryškesnių epizodų iš Lietuvos užsienio politikos tarp dviejų pasaulinių karų. Jau 1920 metų vasarą Lietuva sutiko duoti leidimą naudotis savo teritorija Raudonajai armijai, tuo metu vykdžiusiai lemtingą puolimą prieš Lenkiją, nors oficialiai skelbėsi esanti „griežtai neutrali“. Taigi Lietuva padëjo Raudonajai armijai pulti, nors nebuvo paslaptis, kad ta armija siekè sovietizuoti ir Lenkiją, ir pačią Lietuvą. O tų pačių metų rudenį Lietuvos kariuomenė faktiškai padèjo Raudonajai armijai kovoje su Lenkija Suvalkijoje ${ }^{28}$.

1923 metu pavasarį Lietuva ėmėsi gana rizikingų veiksmų Klaipèdos bei Vilniaus kryptimi ir dejo viltis į Sovietų Rusijos karo paramą ${ }^{29}$. Dèl to vos nekilo naujas karas Rytu Europoje. 1925 metu pabaigoje ir 1926 metu pradžioje Lietuva pati siūlè slaptą karo sajungą Sovietų Sajungai prieš Lenkiją, bet TSRS tuomet nebuvo pasiruošusi karui ${ }^{30}$. 1927-1928 metais vèl dèl avantiūristinių Lietuvos veiksmu vos nekilo karas regione. O 1929 metais Lietuvos, kaip revizionistinès valstybės, įvaizdis tarptautinejje arenoje jau buvo toks stiprus, kad net TSRS Užsienio reikalų liaudies komisaras Litvinovas atsisakè atvykti oficialaus vizito į Kauną. Mat toks vizitas, jo nuomone, būtų kèlęs įtarimą tarptautinei nuomonei, kad TSRS ieškanti susitarimo karui ${ }^{31}$.

Ketvirtajame dešimtmetyje Lietuvos elgesyje galima pastebėti ryškejjančias atsakomybès ne tik už savo, bet ir už viso regiono saugumą apraiškas, tačiau Europa tuo metu jau nesustabdomai judejjo naujojo karo link. Taigi neišvengiamai kyla klausimas, ar dèl II-ojo pasaulinio karo pagrịstai kaltinant didžiąsias valstybes, pirmiausia nacistinę Vokietiją, taip pat stalininę Sovietų Sąjungą, galima kartu visiškai ignoruoti mažų valstybiu - tokių kaip Lietuva atsakomybę?

Pretenzijos Sovietų Sajungai paprastai grindžiamos tuo, kad, atlikdama agresiją prieš Baltijos valstybes, ji sulaužiusi begalę įsipareigojimu, fiksuotu jos pačios pasirašytose sutartyse. Formalios raidès požiūriu to nenuneigsi. Bet istoriniu požiūriu ne vis viena, kokios konkrečiai buvo tos sutartys, kaip jos buvo pasirašomos ir koks buvo jų poveikis to meto politiniams procesams.

\footnotetext{
${ }^{28}$ Laurinavičius Č., Lietuvos - Sovietu Rusijos taikos sutartis, Vilnius, Valstybinis leidybos centras, 1992, p. 131-166.

${ }^{29}$ Senn A. E. „The Great Powers, Lithuania and Vilna Question 1920-1928“, Leiden, 1966, p. 105-136.

${ }^{30}$ Kasparavičius A., Didysis X Lietuvos užsienio politikoje. 1926 metu Lietuvos ir Sovietu Sajungos nepuolimo sutarties sudarymo analizé, Vilnius, 1996. p. 61-74.

31 "Augustino Voldemaro užsienio politika ir Lietuvos geopolitika 1927-1929“, žr. Laurinavičius Č., Politika ir diplomatija, Kaunas, 1997, p. 188-226.
} 
Pavyzdžiui, aptarkime Lietuvos - Sovietų Rusijos vadinamają taikos sutarti, pasirašytą 1920 metų liepos 12 d. Maskvoje. Pagal formalią tos sutarties raidę Lietuva gavo nepriklausomybės su Vilniumi pripažinimą. Tai, žinoma, reikšminga aplinkybè Lietuvai. Tačiau ne mažiau reikšminga ir ta aplinkybè, kad prie tos sutarties buvo priedas, leidęs Raudonajai armijai, tuo metu vykdžiusiai puolimą prieš Lenkiją, naudotis Lietuvos teritorija ${ }^{32}$. Aplinkybių analizè taip pat neleidžia rimčiau abejoti, kad jeigu tokio priedo nebūtų buvę, nebūtu ir pačios sutarties. Vadinasi, tą Lietuvos - Sovietų Rusijos sutarti galima vertinti tik turint galvoje Sovietų Rusijos - Lenkijos karo kontekstą. Tam karui baigiantis, 1920 metų rudenį, Sovietų Rusija Rygoje pasirašė sutarti su Lenkija, kuria faktiškai pakeitè savo sutartį su Lietuva. Nes jeigu pagal menamą Maskvos sutarties interpretaciją Rusija turèjo garantuoti Lietuvą su Vilniumi, tai pagal Rygos sutarties dvasią Rusija leido Lenkijai užimti Lietuvos rytinę dalį su Vilniumi, o pati Rusija net prarado bendrą sieną su Lietuva ${ }^{33}$.

1926 metų rugsėjo 28 d. sovietai pasirašė vadinamąją nepuolimo sutartį su Lietuva, kuria formaliai patvirtino, kad 1920 metu liepos 12 d. sutartis tebegaliojanti. Tačiau Lenkijai užprotestavus, 1932 metais sovietai pasirašè nepuolimo sutartį su Lenkija, kuria patvirtino Rygos sutartị. 1934 metų balandžio 4 d. TSRS pratęsè savo 1926 metų sutarties su Lietuva galiojimą, tačiau Lenkijai vèl užprotestavus, po mėnesio, TSRS pratęsė 1932 metų sutarties su Lenkija galiojimą. Taigi susidare sutarčiu kolizija arba tiksliau - spekuliavimas sutartimis, kurios turèjo visiškai priešingą viena kitai reikšmę.

Žinoma, Lietuva gali sakyti, kad veikè jai priimtina versija pagal 1920 metų Maskvos sutarti, bet Lenkija gali teigti, kad veikẻ jai palanki versija pagal 1920 metų Rygos sutartị. Tačiau istoriniu požiūriu akivaizdu, kad visos tos sutartys ne tvirtino stabilumą bei teisètumą regione, bet priešingai - ji nuolat silpnino ${ }^{34}$.

Beje, neapibrěžtos buvo ne tik dvišalės, bet ir kolektyvinès sutartys regione. Turima galvoje sutartis dèl Briando - Kellogo pakto įsigaliojimo regione (vadinama Litvinovo protokolu), pasirašyta 1929 metais Maskvoje ${ }^{35}$, taip pat sutartis dèl agresijos apibrèžimo, pasirašyta 1933 metais Londone. Reikalas tas, kad tų sutarčių prasmès interpretavimas priklausẻ nuo to, koks geografinis išsidėstymas buvo tų valstybių. Kadangi tas sutartis pasirašè TSRS, viena vertus, ir jos tikros kaimynės, kita vertus, Lietuva nedalyvavo, tai tų sutarčių bendra prasmẻ buvo ta, kad visiems pripažįstami ịsipareigojimai buvo per tas sienas. Konkrečiai Lietuvos ir Lenkijos ginčo atžvilgiu tos sutartys liudijo, kad pripažistama teisèta padètis pagal Rygos, o ne pagal Maskvos sutarti. Todèl Lietuva ėmėsi visų įmanomų žygiu, kad jai rašantis atskirai su TSRS minimas sutartis, jose

32 Sirutavičius V., Nekrašas E.,Lopata R., sudar., Svarbiausios Lietuvos Respublikos tarptautinés sutartys 1918-1995, Vilniaus universiteto leidykla, 1997, p. 13-30.

${ }^{33}$ Laurinavičius Č., (28 išnaša) p. 131-166.

${ }^{34}$ Kam Lietuvos neipareigojo lenku - sovietų Rygos sutartis, žr. Laurinavičius Č., Politika ir diplomatija, p. 134-144.

${ }^{35}$ Litvinovo protokolas (1929 metu vasario 9 d.) ir Lietuvos diplomatija žr. Laurinavičius Č., Politika ir diplomatija, p. 157-187. 
būtu vienaip ar kitaip fiksuotas Maskvos sutarties galiojimas. Ir TSRS pasistengdavo daugiau mažiau patenkinti Lietuvos norus - tik ne tiek dẻl užuojautos nuskriaustai Lietuvai, kiek dẻl to, kad Lietuvos ir Lenkijos pozicija liktų nesutaikomai skirtinga.

Akivaizdu, kad Lietuvos - TSRS ir Lenkijos - TSRS sutarčiu pynė ne tik darè padètį regione neapibrèžtą, bet ir kẻlè tiesioginę grèsmę Lietuvos, Lenkijos, taip pat Latvijos, Estijos saugumui. Akivaizdu, be to, kad tokia padetis tiesiog padèjo revanšistiniams TSRS bei Vokietijos tikslams. Beje, neatsitiktinai ir ju slaptajame 1939 metų rugpjūčio 23 d. protokole buvo fiksuoti Lietuvos interesai Vilniaus atžvilgiu.

Kita vertus, tokia padètis negelbëjo ir TSRS saugumui. Pastarajị teigini tenka pabrèžti, nes naivu samprotauti tokiu būdu, tarsi TSRS apskritai neturëjo teisès į savo saugumą (nors skaitant dabartinę lietuvišką publicistiką, gali susidaryti tokia nuomonè). Kitas dalykas, kad tos šalies saugumas paprastai istorijoje buvo realizuojamas agresyviomis priemonėmis - taip pat, kaip ir ekspansiniai tos šalies siekiai. Vadinasi, yra labai svarbu ne tik identifikuoti ekspansinius siekius bei stengtis užkirsti kelią jiems, bet taip pat svarbu neprovokuoti tu ekspansinių siekiu, kuriuos po to menamai galima būtų vertinti ir kaip saugumo paieškar.

Tokios ambivalentinès situacijos iliustracija istorijoje gali būti vadinamoji neutraliteto politika, kurios ėmėsi Lietuva, taip pat Latvija bei Estija nuo 1938 metų rudens. Formaliai žiūrint, tokia savo politika Baltijos valstybės siekė nesikišti ị vis augančią įtampą tarp didžiuju valstybių blokų ir konkrečiai likti neutraliomis tarp TSRS ir Vokietijos. Tačiau faktiškai Baltijos valstybėms nepavyko išlikti neutraliomis. Savo neutralumo paskelbimu jos užèmè naudingą Vokietijai poziciją - ir ne tik faktiškai, bet ir sąmoningai, nes jos tai padare patartos Berlyno $^{36}$. Dèl šios priežasties tokia Baltijos valstybiu politika prisidèjo prie TSRS ir Vakarų valstybių derybų 1939 metų žlugimo - nors visko, aišku, nelėmè. Tuo pačiu tokia Baltijos valstybiu politika pasitarnavo TSRS ir Vokietijos 1939 metų susitarimams - nors vél nieko nelèmé ${ }^{37}$.

Taigi jeigu TSRS ir jos paveldètoja Rusijos Federacija atsakinga už 1940 metais ịvykdytą agresiją prieš Lietuvą, tai ar neatsakinga ir Lietuva už tos agresijos nuolatini provokavimą? Taip pat ar neatsakinga ir Lenkija už 1939 metais susidariusią situaciją. Beje, ir kitų agresijos aukų būtų galima panašiai paklausti...

\footnotetext{
${ }^{36}$ Laurinavičius Č., The Baltic States between the World Wars: Foreign Policy Options and the Problem of Neutrality, in Die baltische Staaten im Schnittpunkt der Entwicklungen. Verganenheit und Gegenwart. Herausgegeben von Carsten Goehrke und Jürgen von Ungern - Sternberg. Schwabe \& Co.AG. Verlang. Basel, 2002, p. 121-132.

${ }^{37}$ Ahman R., The German Treaties with Estonia and Latvia on 7 June 1939 - Barganing Play or Alternative for German - Soviet Undrestanding? Journal of Baltoc Studies, vol. XX, no. 4., Winter 1989, p. 337-364; Feldmann I., Stranga A., Latvia and the Baltic Policies of the USSR, Poland and Germany in the Late 1930's, Procedings of the Latvian Academy of Science Section A, 1994, no. 3, p. $9-15$.
} 


\section{Vietoje išvadụ: ar reikalinga istorija santykiuose tarp valstybių?}

Be abejo - reikalinga, nes net ir paviršutinis bei epizodinis žvilgsnis i ją leidžia pamatyti tarsi kino juostoje laiko užšaldytus tautu siekių, pergalių bei pralaimèjimu, džiaugsmų bei kančių fragmentus. Jie žadina jausmus ir protą. Ju tiesiog reikia žmogiškai prigimčiai. Jų reikia visuomeniniam bei tarptautiniam bendravimui Tačiau vargu ar patys savaime jie gali pagelbèti santykiams tarp valstybių, lygiai kaip ir pakenkti. Nes tų santykių praeitis dažniausiai labai marga, joje galima rasti visko. O kita vertus, tos praeities sąranga tokia, kad niekada nebus lemta iki galo sužinoti, kaip iš tikrujų buvo.

Vis dèlto net ir fragmentinis požiūris į Lietuvos ir Rusijos santykius XX amžiaus pirmoje pusëje leidžia suprasti, kad ne taip jau viskas buvo paprasta ir vienareikšmiška. Kad nebuvo nei absoliučios tiesos nei be kaltės kaltumo. Todèl iš tos istorinės praeities bandyti prieiti prie visiems tinkančios išvados gresia istoriją paverti ideologija ar tiesiog politika.

Zinoma, galima kaltės dydị bandyti matuoti, galima taikyti skirtingus baudžiamojo kodekso straipsnius, taip pat galima ieškoti švelninančių aplinkybių ir pan. Tačiau ir tokiu atveju negalima nesiskaityti su realijomis. Nes aišku, kad esamomis aplinkybėmis istorinès kaltès kodifikavimas galès būti ko nors realaus vertas tik tuo atveju, jeigu ji pripažins abi pusės.

Bet pakalbėkime detaliau, kokios tos realijos. Akivaizdu, kad Lietuva savo ginče su Rusija negali sutikti su versija, kad 1940 metais ji ne prievartos keliu, bet savo noru atsisakè nepriklausomybès. Tokios versijos Lietuva negali priimti dèl istorinių faktu, taip pat dèl savo šiandieninių konstitucinių aktu, dèl oficialios civilizuoto pasaulio pozicijos tuo klausimu, pagaliau svarbiausia dèl elementarios savigarbos bei dèl savo politinès identifikacijos pagrindu.

Tačiau vargiai galima būtu tikètis, kad Rusija oficialiai pripažins savo atsakomybę už 1940 metais atliktą Lietuvos okupaciją su visomis dẻl jos atsiradusiomis pasekmėmis. Neabejotina, kad dabartinè RusijosVvyriausybė nežengs tokio žingsnio, nes juo pakirstų savo imperinius siekius, kuriu, be abejo, turi. Tačiau reikia taip pat suprasti, kad toji pati Rusijos Vyriausybẻ nežengs tokio žingsnio ir dèl pačios Rusijos valstybès saugumo sumetimų. Bet svarbiausia, neverta tikètis tokio žingsnio iš Rusijos, nes jam nepritartu dauguma rusų tautos. Ne tik dèl to, kad rusai turi stiprų imperini geną, bet ir dèl to, kad tai, ju nuomone, būtų tiesiog neteisinga.

Žinoma, Lietuva gali bandyti nekreipti dėmesio į Rusijos interesus ir vadovautis savo interesais. Pirmiausia interesu kovoti su rusiškos ekspansijos apraiškom. Taigi Lietuva ir toliau gali ryžtingai reikalauti iš Rusijos, kad ji galu galeprisipažintu ịvykdžiusi okupaciją. Bet tada realizmas reikalautu ịvertinti jẻgas, kuriomis galima būtų remtis tokioje pozicijoje.

Civilizuotas pasaulis, žinoma, nepripažino 1940 metų Lietuvos aneksijos. Apie tai liudija kad ir ta aplinkybè, kad dauguma Vakaru valstybiu, su kuriomis Lietuva 1918-1940 metais palaikè diplomatinius santykius, Lietuvai 
1991 metais atgavus faktinę nepriklausomybę su ja atnaujino diplomatinius santykius, o ne užmezgè kaip su nauja valstybe. Apskritai Vakarų valstybės, galima sakyti, priima Lietuvos versiją dèl 1940 metų įvykių ir dèl Lietuvos valstybės tęstinumo.

Tačiau, kita vertus, negalima nematyti, kad kitų valstybių pozicijoje tuo klausimu yra tam tikro dvilypumo. Viena vertus, palaikydamos Lietuvos poziciją arba parodydamos supratimą jos susirūpinimu dèl jaučiamos grèsmės iš Rusijos pusės, kita vertus, tos valstybės Rusiją laiko savo strategine partnere ir oficialiai deklaruoja, kad nesiruošia kèsintis į Rusijos saugumo interesus. Toki valstybių elgesi galima vertinti kaip elementarų etiketą, kaip politinį interesą neaštrinti esančiu pozicijų skirtumo tarp Rusijos ir Lietuvos (bei kitu Baltijos valstybių), tikintis, kad per laiką tas skirtumas mažès. Tačiau tokiame elgesyjetiksliau, kai kuriuose jo simptomuose, galima įžvelgti ir kažką panašaus ị tai, kokios politikos laikèsi TSRS tarpukaryje Lietuvos ir Lenkijos ginčo atžvilgiu, kai vienai pusei buvo sakoma viena, o kitai kita, bet su tikslu, kad tų dviejų šaliu pozicijos nesuartètu...

Kitas veiksnys, kuriuo Lietuva savo reikalavimuose Rusijos atžvilgiu gali remtis, yra pati lietuvių tauta, nukentëjusi dèl okupacijos bei tremčių ir kitokiu represijų. Tačiau ir šiuo atžvilgiu nėra padètis vienareikšmè. Nors dauguma Lietuvos gyventoju sutinka, kad Rusija kelia grèsmę Lietuvai, tačiau taip pat dauguma tų gyventojų rusus laiko sau artimiausiais bei draugiškiausiais iš kitu tautu. Iš Rusijos pusės taip pat sklinda draugiški atsiliepimai apie lietuvius, tiksliau apie „litovskij narod“. Ir tuo pačiu metu paskutinès apklausos Rusijoje rodo, kad ten priešiškiausiomis valstybėmis laikomos Baltijos valstybės, kartu ir Lietuva.

Visa tai verčia kelti tokio pobūdžio klausimus: ar Lietuva vardan savo saugumo interesų ryžtingai varydama Rusiją i kampą drauge nestumia pati savęs į naują tarptautinę izoliaciją? Ir ar vesdama ryžtingą propagandinį karą su Rusija Lietuva pati nepadeda naujos versijos apie Lietuvos ir Rusijos „liaudies masiu jungimą" formavimui?

Kaip bebūtu, esamos politinès realijos turètų versti Lietuvą rimtai susimąstyti dèl savo politikos santykių su Rusija apskritai ir dèl istorijos vaidmens tuose santykiuose konkrečiai. Politinė kultūra reikalautų su istoriniais faktais bei ju interpretacijomis elgtis korektiškiau, nenusižengiant moralumui. Politikams, besirūpinantiems nacionaliniais interesais, nereiktų būti kurtiems kitos pusės argumentams. Tai, žinoma, nèra lengva ir bendras visiems atvejams receptas vargu ar įmanomas. Tam tikru kriterijumi galètų būti Vakarų Europos visuomenès. Ten istorijos vaidmuo santykiuose tarp valstybiu yra mažesnis nei postkomunistiniame pasaulyje. Ten vengiama santykiu istoriją tarp valstybiu padaryti vidaus problemu i ikaite, nes Europoje stengiamasi išvengti konfliktų, kurie vertinami pagal istorinius vertinimus. 